\title{
Perspectives of Life in Sweden During the COVID-19 Pandemic
}

\author{
Karin Weman Josefsson
}

Halmstad University

\begin{abstract}
Sweden has adopted a somewhat different approach to handle the corona pandemic, which has been widely debated both on national and international levels. The Swedish model involves more individual responsibility and reliance on voluntary civic liability than law enforcement, while common measures in other countries are based on more controlling strategies, such as restrictive lockdowns, quarantines, closed borders, and mandatory behavior constraints. This commentary aims to give a brief overview of the foundations of the Swedish model as well as a discussion on how and why it has been adopted in the Swedish society based on Swedish legislations, culture, and traditions. Finally, perspectives on how the Swedish model could be connected to the tenets of selfdetermination theory will be discussed.
\end{abstract}

Keywords: health behavior, motivation, self-determination

When corona swept across the world, many countries tried to limit the contagion using restrictions based on lockdown, forced quarantine, and other strategies to control citizens' actions, in some cases supported by police or military enforcements and legislations to regulate violations. Sweden received worldwide attention for their unique approach to the pandemic that refrained from countrywide lockdowns. Swedes were criticized for what was viewed as a softer approach that favored "herd immunity" and was labeled as "the Swedish Gamble" (Vogel, 2020). There were perceptions from around the world that Sweden neglected to take necessary measures to slow the spread of the virus (Irwin, 2020).

To understand the Swedish approach, you need to know that this country has a long history of high trust in authorities, institutions, and science (Falk, 2020). It is also written in the Swedish constitution that expert authorities (and not politicians) guide these kinds of situations, and military forces are not allowed to intervene in civil matters in times of peace (only in times of war). This means that even if the government can control how the expert authorities, such as the Public Health Agency (the Swedish equivalent to Centers for Disease Control and Prevention) should work, they cannot overrule or interfere with their ongoing work to gain personal or political

Weman Josefsson (Karin.Weman@hh.se) is with the School of Health and Welfare, Halmstad University, Halmstad, Sweden. 
benefits, or from public pressures. Of course, politicians have the official power in the end, but in this sense, the Swedish constitution is different from many other countries. Swedish law also ensures that Swedes have the right to move freely, and the Swedish Infectious Diseases Act 2004:168 (Socialdepartementet, 2004) does not allow forced lockdown. The government passed a temporary exception to this law for 3 months (starting April) where they potentially could have decided on some degree of lockdown, but it was never used as the infection rates slowed down markedly. A more elaborate (but also temporary) pandemic law to allow more restrictive measures were taken into effect in January 2021. Still, the Public Health Agency of Sweden states that they do not believe public health work should build on controlling measures or punishment and traditionally use recommendations and appeals to trust and volition instead, which has proven to be effective in many cases. As an example, 95-98\% of Swedish parents follow the children vaccination programs voluntarily (Smittskyddsinstitutet, 2005). Hence, a combination of legislation and tradition to avoid rules and paternalism, aiming to facilitate peoples' motivation to act wisely and sensibly by their own goodwill, is deeply rooted in Swedish public health work.

There is a misconception that the Swedish COVID-19 approach is not regulated by law, and perhaps this is a case of semantics and how the concepts of "general advice" and "recommendations" are interpreted, making it sound more voluntary than it is. General advice from the Public Health Agency is not binding but is a strong recommendation about how you are expected to behave to comply with a law or a regulation (Folkhälsomyndigheten, 2020a). There are more restrictive rules that apply, for example, to public events (e.g., that any audience at cultural or sports event must be sitting down with $1-1.5 \mathrm{~m}$ distance) and restaurants (e.g., table service only, maximum eight guests per table, no alcohol serving after 08:00 p.m., etc.). According to Swedish Infectious Diseases Act 2004:168 (Socialdepartementet, 2004), everyone has a personal responsibility to prevent the spread of infectious diseases, and it is this responsibility authorities appeal to when they ask (not force) the Swedish people to follow the recommendations of social distancing, hand hygiene, protecting our older adults and the vulnerable, work from home, and avoid parties and unnecessary travels - and to do it in solidarity and respect for each other and the people who work hard in health care. Solidarity is a word with a long history in Sweden that may have been watered and mainly politically annotated with time, but rediscovered in a crisis that affects all citizens, regardless of political standpoint. It is a positive and strong word that encourages people to stand together and care for each other in times of need. Support your local hairdresser and restaurant but act responsible and use common sense. Gallup polls during the pandemic also show that $70-80 \%$ of the Swedish population support the Swedish corona strategy and trust the authorities (Falk, 2020).

\section{A Belief in Sustainable and Bearable Measures}

The Swedish Public Health Agency has from the beginning of the pandemic openly stated that controlling strategies, such as lockdowns, will (at best) work short-term (especially in democratic societies) and will do more harm than good in this 
situation. The chief epidemiologist has repeatedly stated that handling the corona crisis is "a marathon, not a sprint," and stresses the need for sustainable restrictions that people can not only tolerate for a long period of time, but also does not change back and forth (such as opening and closing lockdowns), challenging peoples' patience. From the beginning, the Public Health Agency has also emphasized a holistic public health approach, not only focusing on the COVID-19 health risks, but also other health consequences on a societal level that could have negative side effects of more severe measures, such as lockdowns (e.g., overlooked cancer diagnoses and physical and psychological effects of physical inactivity, economic recession, unemployment, social isolation). Therefore, the primary schools, restaurants, hairdressers, and other businesses have been allowed to remain open, although high schools and universities shifted to online classes. Even gyms, sport clubs, swimming facilities, and team sports for all ages have been allowed open during the entire pandemic, as sports and recreation activities are highly promoted by the Public Health Agency (with outdoor activities especially encouraged). The general advice on physical activity is that sports competitions and training sessions can be performed in all sports on any levels but should primarily be held outdoors and avoiding crowding, providing hand hygiene possibilities, and held in accordance with the main restrictions for public events (Ödman, 2020). As in many other European countries, Sweden has recently had surging infection rates, and the Public Health Agency has applied more stringent restrictions (e.g., recommending people to temporarily avoid gyms, sport competitions and other social events, unnecessary travel, limit social contacts outside the own household, etc.) to control the rising spread.

\section{Motivation Theory Perspectives}

One of the key arguments from the Swedish authorities regarding the COVID-19 approach is that a softer strategy is more sustainable in the long term not forcing people by closing society and restricting their lives, and there is evidence to support that. We often try to control people by default; however, controlling strategies might eventually backfire because humans don't like to feel controlled and because it encourages cheating, loafing, and violations (Ryan \& Deci, 2017). We have evidence that riots and demonstrations across the world represent a backlash from removing personal responsibility as the driving motivator and instead relying on extrinsic factors for motiving human behavior, such as national mandates. It is more effective when people do things because they want to do it and believe it is meaningful (instead of trying to avoid punishments) because then they will sustain and self-regulate the behavior even in the face of barriers.

The Swedish approach could therefore be connected to the tenets of selfdetermination theory (SDT; Ryan \& Deci, 2017), and the value of three basic psychological needs for motivation and behavior. When fulfilled, the psychological needs autonomy (feelings of volition and choice), competence (feeling effectiveness and mastery), and relatedness (feeling connected to other people) stimulate human growth and well-being as well as self-regulation and selfdetermined motivation. If the needs are frustrated or thwarted, on the other hand, and people feel controlled, helpless, or isolated, the motivational regulations 
will be based on external forces which are less sustainable and depending on contingent rewards or punishments (carrot and stick).

Sweden's softer policy and recommendations for social distancing have been widely criticized, and even called experimental, but so far, it seems to work more or less the same (i.e., as good or bad in terms of mortality, economy, unemployment, etc.) as many other countries with stricter and more controlling policies (e.g., Belgium, Spain, Italy). Both mobile net data and polls show that many Swedes practice social distancing voluntarily in accordance with the recommendations (Orbe et al., 2020; Falk, 2020). Also, 86\% reported they spent their summer vacation at local destinations (i.e., "staycation" or "hemester" in Swedish) instead of the usual travels (Englund, 2020; Novus, 2020) and travels during the autumn school leave ("höstlovet" in Swedish) decreased with 20-30\% compared with 2019 (Folkhälsomyndigheten, 2020b). Experts have stated that the Swedish measures based on voluntariness, trust, and reason are right for the Swedish context but would perhaps not work in other countries. This might be true in part, as trust and transparence between authorities and citizens is a fundamental part of it, but the basic psychological needs (autonomy, competence, and relatedness) underpinning the motivational regulations in SDT are universal and applies to people of all ages and cultures (Ryan, \& Deci, 2002, 2017; Deci, \& Ryan, 2000). There is also a large COVID-19 project in Belgium based on SDT on how to create a motivating climate when the populations' patience to follow the guidelines fail (Vansteenkiste et al., 2020) supporting the assumption that more autonomy supportive approaches might be used in other countries.

Recently, and in the face of surging cases in Europe, the World Health Organization European unit stated that lockdowns should only be used as a "last resort" due to collateral damage, in terms of, for example, mental health, domestic violence, and prevention and management of other health issues (Kluge, 2020). An observational study on the impact of country level actions showed that full lockdowns was not related to decreased number of critical cases or overall mortality (Chaudhry, Dranitsaris, Mubashir, Bartoszko, \& Riaz, 2020); however, no causal inferences can be drawn given the exploratory observational design. Another study showed no significant benefits from mandatory lockdown compared to voluntary measures in any of the 10 countries compared in the study, and harsh restrictions did not seem to protect vulnerable populations (Bendavid, Oh, Battacharya \& Ioannidis, 2021). Also, in the Great Barrington Declaration (Kulldorff, Bhattacharya, \& Gupta, 2020), a group of infectious-disease experts called for an end of lockdowns to tackle COVID-19, claiming that lockdown harms public health and is "a terrible experiment." The Public Health Agency of Sweden stated at the beginning of the pandemic that other measures are preferred over lockdown to flatten the curve and to prevent health care overload. In fact, despite Sweden's high death tolls, Swedish health care and intensive care units so far never reached its limits, and the emergency field hospitals that were built during spring could be mounted down without being used. Hopefully, they will not be needed even in the future, but this virus has surprised the world several times before so no one can be sure.

An important note is that Swedish authorities never claimed to have the best solution, or even knowing their model will be more successful than any other. They simply let the experts lead the way, judging the available evidence, adjusting according to upcoming situations while also following Swedish laws and traditions. 
It is also important to note that some parts of the strategy have failed, such as the early mass testing and tracing, which was delayed for months before full capacity came in to place. In addition, some of the information could have been adapted to different target groups, contain less bureaucratic language, and be communicated in different contexts and channels and with various methods to reach the parts of the population more susceptible to social media rumors and fake news. The high death tolls in the older adult population is also considered a domestic failure. At the same time, other European countries have as high or even higher death tolls per 100,000 population than Sweden despite strict lockdowns and compulsory use of face masks (e.g., United Kingdom, Belgium, Spain), and most countries in the world have actually failed to protect older adults (Comas-Herrera et al., 2020). It is noticeable that some countries that applied tougher measures and obligatory masks in the "first wave" during spring still got hit hard by the "second wave," implying tougher measures were no guarantee of controlling this disease, not even for some of the countries that successfully controlled the virus in spring. It is easy to look in the mirror and judge what we should have done, but every country has had to act on available information and evidence at any given time, and even with the rapidly mounting studies on COVID-19, there is still much to be learned before scientists know how to make sense of this pandemic.

Between March and October 2020, the Public Health Agency held over 100 press conferences, for $1 \mathrm{hr}$ each, on COVID-19 updates. During the most intense period of the pandemic, they were held daily, but since the infection rates slowed down during summer, they have been held twice a week. The Public Health Agency recently declared that they plan to continue with these press conferences for at least until autumn 2021. The regular press conferences together with the written reports published on a weekly basis on their website have helped people keep evidence-based track of the pandemic progress, understand how the authorities work and get critical questions answered by experts open for debate, and discussing different views. They provide meaningful rational for people to act responsible and prevent the infection to spread, and this autonomy-supportive approach might help citizens internalize the restrictions because they find it important, trust the system, and feel societal affiliation.

One way to control the pandemic (or emerging endemic) and go back to some kind of "new normal," is to develop herd immunity, which can be obtained in two ways - either by a certain number of people in the population getting infected and developing antibodies or by vaccination (World Health Organization, 2020). This means that all countries need herd immunity but reaching it by letting people getting infected will cost too many lives, and as we do not know how effective the COVID19 vaccines will be over time, it is possible that the world will have to live with this virus for years before vaccines can help us handle this situation well enough. In turn, this means that sustaining the behavioral measures to flatten the curve (social distancing, hand washing, working from home, etc.) will be crucial to reduce the public health and societal damage until a proper and continuous vaccine program becomes available on a global level.

In summary, nobody knows which strategy will turn out to be more successful than another in the end, and all countries do the very best they can with the current knowledge and resources available (e.g., health care insurance system). Behavior is the most important factor to control the virus, and there are a 
number of evidence-based methods for communicating motivational messages and policies for sustainable behavior based on SDT (Vansteenkiste et al., 2020). There are also communication models to avoid, which can have the opposite effect. When people feel helpless, incompetent and controlled, do not see the meaning and value of the activity, feel exposed and isolated, receive conflicting information, and so forth, they lose the psychological energy (motivation) required to follow the restrictions. Regardless of the overall actions on country level, many governments could benefit from targeting the motivational drives needed for people to willingly act responsible and solidary to endure this COVID-19 marathon.

\section{Acknowledgments}

This article is based on personal perspectives from an individual and academic who has been living in Sweden before and during the pandemic, and other individuals who live in Sweden may hold different views. There may also be differences related to age, occupation, region, and other categorical distinctions in response to and perception to the virus within Sweden.

\section{References}

Bendavid, E., Oh, C., Bhattacharya, J., \& Ioannidis, J.P.A. (2021). Assessing mandatory stay-at-home and business closure effects on the spread of COVID-19 European Journal of Clinical Investigation,. doi:10.1111/eci.13484

Chaudhry, R., Dranitsaris, G., Mubashir, T., Bartoszko, J., \& Riaz, S. (2020). A country level analysis measuring the impact of government actions, country preparedness and socioeconomic factors on COVID-19 mortality and related health outcomes. EClinicalMedicine, 25, 100464. Retrieved from https://www.sciencedirect.com/science/article/ pii/S258953702030208X

Comas-Herrera, A., Zalakaín J., Lemmon, E., Henderson, D., Litwin, C., Hsu, A.T., . . . Fernández, J.-L. (2020, October 14). Mortality associated with COVID-19 in care homes: International evidence. International Long-Term Care Policy Network, CPECLSE. Retrieved from https://ltccovid.org/2020/04/12/mortality-associated-withcovid-19-outbreaks-in-care-homes-early-international-evidence/

Deci, E.L., \& Ryan, R.M. (2000). The "what" and "why" of goal pursuits: Human needs and the self-determination of behavior. Psychological Inquiry, 11(4), 227-268. doi:10. 1207/S15327965PLI1104_01

Englund, I. (2020, November 11). Hemester: Borta bra eller hemma bäst? [Staycation: Away is good but home is best]. Novus. Retrieved from https://mb.cision.com/Public/ 121/3137723/a8e0f4c6265cf95b.pdf

Falk, E. (2020). Förtroende för samhällsinstitutioner i de nationella SOM-undersökningarna 1986-2018 [Confidence in social institutions in the national SOM surveys 1986-2018] [SOM-rapport nr 2020:1]. Retrieved from https://www.gu.se/som-institutet/resultatoch-publikationer/rapporter

Folkhälsomyndigheten. (2020a, October). How to reduce the spread of COVID-19. Folkhälsomyndigheten. Retrieved from https://www.folkhalsomyndigheten.se/thepublic-health-agency-of-sweden/communicable-disease-control/COVID-19/

Folkhälsomyndigheten. (2020b, November). Veckorapport om COVID-19, vecka 44. [Weekly report on COVID-19, week 44]. Folkhälsomyndigheten. Retrieved from 
https://www.folkhalsomyndigheten.se/folkhalsorapportering-statistik/statistik-ao/ sjukdomsstatistik/COVID-19-veckorapporter/

Irwin, R.E. (2020). Misinformation and de-contextualization: International media reporting on Sweden and COVID-19. Globalization and Health, 16(62), 1-12.

Kluge, H.H.P. (2020, October 15). Statement-COVID-19: An update on the COVID-19 situation in the WHO European Region. World Health Organization. Statement to the press, October 15, 2020. Retrieved from https://www.euro.who.int/en/mediacentre/sections/statements/2020/statement-covid-19-an-update-on-the-covid-19situation-in-the-who-european-region

Kulldorff, M., Bhattacharya, J., \& Gupta, S. (2020). The great Barrington declaration. Retrieved from https://gbdeclaration.org/ retrieved 2020-11-03

Novus. (2020). Resultat av ny Novus-undersökning: Det här tyckte svenskarna var bäst med att semestra hemma [Results of a new Novus survey: This is what the Swedes thought was best about holidaying at home]. Retrieved from https://www.landshypotek. se/om-landshypotek/press 1/2020/resultat-av-ny-novus-undersokning-det-har-tycktesvenskarna-var-bast-med-att-semestra-hemma/ retrieved 2020-11-11

Ödman, P. (2020). Gemensamma författningssamlingen avseende hälso- och sjukvård, socialtjänst, läkemedel, folkhälsa m.m. [General constitutional collection regarding health and medical care, social services, medicines, public health, etc.]. ISSN 20021054, Artikelnummer 27120012HSLF. Socialstyrelsen. Retrieved from https://www. folkhalsomyndigheten.se/contentassets/6250183ea135423f8ed6f20c86ef2d04/hslf-fs45-2020.pdf

Orbe, J., Lundqvist, A., \& Karlsson, L. (2020). Rapport om förtroende, oro och beteende under coronakrisen oktober [Report on trust, anxiety and behavior during corona crisis october]. Kantar Sifo. Rapport till MSB 2020-11-04. Retrieved from https://www.msb. se/sv/aktuellt/pagaende-handelser-och-insatser/msbsarbete-med-anledning-av-corona viruset/kantar-sifos-rapport-om-fortroende-oro-ochbeteende-under-coronakrisen/

Ryan, R.M., \& Deci, E.L. (2002). Overview of self-determination theory: An organismic dialectical perspective. In E.L. Deci \& R.M. Ryan (Eds.), Handbook of selfdetermination research (pp. 3-33). Rochester, NY: University of Rochester Press.

Ryan, R.M., \& Deci, E.L. (2017). Self-determination theory: Basic psychological needs in motivation, development, and wellness. New York, NY: Guilford Press.

Smittskyddsinstitutet. (2005, January). Vaccinationsstatistik från barnavårdscentralerna, insamlad januari 2005 [Vaccination statistics from the childcare centers, collected January 2005]. Smittskyddsinstitutet. Retrieved from http://www.smittskyddsinstitutet.se/ upload/5216/BVCjan2005_050526x.pdf

Socialdepartementet. (2004). Smittskyddslag (2004:168) [Infectious disease act (2004:168)]. Socialdepartementet. Retrieved from https://www.riksdagen.se/sv/dokument-lagar/ dokument/svensk-forfattningssamling/smittskyddslag-2004168_sfs-2004-168

Vansteenkiste, M., Van den Bergh, O., Chauvrier, P., Desmet, A., Dewaele, A., Phalet, K., ... Waterschoot, J. (2020). Report \# 12: The population is no longer motivated. How can we create a motivating climate? Retrieved from https://mcusercontent.com/ ceb1688cb1cd678fa4a780bc5/files/8c2d8ad2-b8cb-42cc-98e0-1c78090e75aa/Report_ 12_Motivational_alarm_signals_final.pdf

Vogel, G. (2020). Sweden's gamble. Science, 370(6513), 159-163. PubMed ID: 33033200 doi:10.1126/science.370.6513.159

World Health Organization. (2020). Science conversation, August 28, 2020. Episode \#1Herd immunity. Retrieved from https://www.who.int/emergencies/diseases/novelcoronavirus-2019/media-resources/science-in-5/episode-1 